\title{
Arsenate toxicity and stress responses in the freshwater ciliate Tetrahymena pyriformis
}

\author{
Yong-Yu Zhang ${ }^{\mathrm{a}}$, Jun Yang ${ }^{\mathrm{a}, * *}$, Xi-Xiang Yin ${ }^{\mathrm{a}, \mathrm{b}}$, Su-Ping Yang ${ }^{\mathrm{c}}$, Yong-Guan Zhu ${ }^{\mathrm{a}, \mathrm{b}, *}$ \\ ${ }^{a}$ Key Laboratory of Urban Environment and Health, Institute of Urban Environment, Chinese Academy of Sciences, Xiamen 361021, China \\ ${ }^{\mathrm{b}}$ Research Center for Eco-environmental Sciences, Chinese Academy of Sciences, Beijing 100085, China \\ ${ }^{\mathrm{c}}$ Department of Bioengineering and Biotechnology, Huaqiao University, Xiamen 361021, China
}

Received 16 August 2011; received in revised form 12 January 2012; accepted 13 January 2012

Available online 16 February 2012

\begin{abstract}
The arsenic metabolism in different biological organisms has been studied extensively. However, little is known about protozoa. Herein, we investigated the cell stress responses of the freshwater ciliate Tetrahymena pyriformis to arsenate toxicity. An acute toxicity assay revealed an $18-\mathrm{h} \mathrm{EC}_{50}$ arsenate concentration of ca. $40 \mu \mathrm{M}$, which caused significant changes in the cell shape, growth and organism mobility. Whereas, under exposure to $30 \mu \mathrm{M}$ arsenate, T. pyriformis could grow reasonably well, indicating a certain resistance of this organism. Arsenic speciation analysis revealed that $94-98 \%$ of the total arsenate in cells of T. pyriformis could be transformed to monomethylarsonic acid, dimethylarsinic acid and a small proportion of arsenite after $18 \mathrm{~h}$ of arsenate exposure, thus indicating the major detoxification pathway by arsenic oxidation/reduction and biomethylation. Finally, comparative proteomic analysis unveiled significant changes in the expression of multiple proteins involved in antioxidation, sugar and energy metabolism, proteolysis, and signal transduction. Our results revealed multiple pathways of arsenate detoxification in $T$. pyriformis, and indicated that protozoa may play important roles in the biogeochemical cycles of arsenic. (c) 2012 Elsevier GmbH. All rights reserved.
\end{abstract}

Keywords: Arsenate toxicity; Tetrahymena pyriformis; Biomethylation; Proteomics

\section{Introduction}

Arsenic (As) is a ubiquitous and potentially toxic element in the environment (Matschullat 2000). Weathering of rocks and anthropogenic point sources contribute mainly to As found in the environment, such as smelter slag, coal combustion, and runoff from mine tailings, etc. Chronic exposure to arsenic through contaminated drinking water or

\footnotetext{
${ }^{*}$ Corresponding author at: Key Laboratory of Urban Environment and Health, Institute of Urban Environment, Chinese Academy of Sciences, Xiamen 361021, China.

** Corresponding author.

E-mail addresses: jyang@iue.ac.cn (J. Yang), ygzhu@ rcees.ac.cn (Y.-G. Zhu)
}

foods occurs worldwide, and is associated with a variety of diseases, including cancer, diabetes and developmental disorders (Kapaj et al. 2006; Tchounwou et al. 2004; Tseng et al. 2002). In natural waters, arsenic exists predominantly as the pentavalent form, As (V). Its mobility and bioavailability is influenced not only by abiotic factors, but also by the activities of aquatic plants, animals and microbes (Alvarado et al. 2008; Čerňanský et al. 2007; Liao et al. 2008).

Arsenic metabolisms in microbes, such as archaea, bacteria, and fungi, have been extensively studied in the past (Tsai et al. 2009). Microbes respond to arsenic in a variety of different ways, such as compartmentalization, exclusion, and immobilization. And many of them can methylate arsenic giving rise to monomethyl, dimethyl, and/or tri-methyl derivates, which are volatile and are rapidly released to the atmosphere 
(Qin et al. 2006; Tsai et al. 2009). However, so far only little is known about arsenic metabolism in free living protozoa, an important and abundant component in aquatic ecosystems. Early in 1988, Amaral et al. (1988) investigated the protein responses of a protozoan Tetrahymena pyriformis to arsenite exposure and revealed an inducement of two main group of stress proteins with molecular masses in the ranges $70-75 \mathrm{kDa}$ and $25-29 \mathrm{kDa}$, whereas due to the technical limitations at that time, not much information was obtained as to what these proteins are and what functions will they perform in the responses to arsenite stress. To the best of our knowledge, this represents the first and only report on arsenic toxicity in a free-living protozoan.

The free-living protozoa are ubiquitous and abundant component of microbial communities, playing a pivotal role in many major element cycles (i.e. carbon, nitrogen, phosphorus, and sulfur). They are represented in all aquatic ecosystems including lakes, reservoirs, streams, wetlands, seas and soils (Corliss 2002; Finlay and Esteban 1998; Hahn and Höfle 2001). Moreover, as unicellular organisms with a short regeneration time, protozoa respond rapidly with great sensitivity to the presence of pollutants in nature. This has resulted in them being used as test systems for assessing ecological risk (Sauvant et al. 1999). In fact, most organisms, from bacteria to mammals, have developed various strategies to counter-act arsenic toxicity or to utilize arsenic as an electron donor/receptor in energy production (Oremland and Stolz 2003; Tsai et al. 2009). Considering the high abundance and important ecological status of protozoa in natural aquatic ecosystems, we hypothesize that protozoa may have also developed certain approaches to tolerate arsenic toxicity. Most recently, Yin et al. (2011) reported the rapid biotransformation of arsenic by the common ciliated protozoa Tetrahymena pyriformis. Studies on arsenate toxicity and stress responses in T. pyriformis are urgently needed. On this basis, T. pyriformis was employed as one case to study the arsenate toxicity as well as the cell stress responses. The results will contribute to our knowledge on the poorly understood arsenic activities and metabolism in protozoa.

\section{Material and Methods}

\section{Cell culture}

Tetrahymena pyriformis Ehrenberg, 1830 (strain GL-C) was obtained from the National Tetrahymena Stock Center of Cornell University, USA. It was maintained in a $100 \mathrm{ml}$ of modified Neff medium containing $0.25 \%$ proteose peptone, $0.25 \%$ Difco yeast extract, $0.5 \%$ glucose and $3.33 \mu \mathrm{M} \mathrm{FeCl}_{3}$ at $30^{\circ} \mathrm{C}$ without shaking.

\section{Arsenate toxicity}

To evaluate the arsenate toxicity, we analyzed growth curves for T. pyriformis under a set of different arsenate concentrations $\quad(0, \quad 10, \quad 50, \quad 100, \quad 150, \quad 200 \mu \mathrm{M}$ $\mathrm{Na}_{3} \mathrm{AsO}_{4} \cdot 12 \mathrm{H}_{2} \mathrm{O}$ ) using the same incubation conditions as described above. Arsenate was added into each culture at $21 \mathrm{~h}$ post-inoculation when T. pyriformis grew into the early exponential phase. Three replicates of each concentration were run. From the beginning of inoculation, subsamples were taken at $3 \mathrm{~h}$ intervals and fixed with glutaraldehyde $(2.5 \%)$. Then the cell abundance of $T$. pyriformis was enumerated by the hemocytometer method using an inverted microscope. Based on growth curves, 18-h arsenate $\mathrm{EC}_{50}$ concentrations were determined, causing a $50 \%$ decrease in growth rate of $T$. pyriformis.

Cell morphology of T. pyriformis grown at different arsenate concentrations $(0$ and $40 \mu \mathrm{M})$ was evaluated with light and scanning electron microscopy methods. For scanning electron microscopy observations, $10 \mathrm{ml}$ of subsamples from each culture were collected at $6,12,18$ and $24 \mathrm{~h}$ after arsenate exposure, and fixed with glutaraldehyde as described above for $30 \mathrm{~min}$ at $4{ }^{\circ} \mathrm{C}$. Via centrifugation $\left(1800 \times g, 4{ }^{\circ} \mathrm{C}\right.$, $10 \mathrm{~min}$ ), the cell pellets were collected and washed by phosphate buffer ( $0.1 \mathrm{M}, \mathrm{pH} 7.2)$ three times. Finally, micrographs were taken with a field emission scanning electron microscope (Hitachi S-4800, Japan).

\section{Arsenate resistance}

To investigate which concentrations of arsenate T. pyriformis can bear, the cells were incubated in a set of media containing increasing arsenate concentrations from 10 to $40 \mu \mathrm{M}$ at intervals of $5 \mu \mathrm{M}$. Finally, growth curves were drawn to observe whether $T$. pyriformis can grow well at different arsenate concentrations.

\section{Determination of arsenic species in T. pyriformis and its culture medium}

Arsenic species in the cells of $T$. pyriformis were determined using a modified method as previously described by Zhang et al. (2009a,b). Briefly, three groups (i.e., the Control, Env and Exp) of T. pyriformis culture ( $100 \mathrm{ml}$ ) at early exponential growth phase were exposed respectively to $0,0.67$ (50 ppb) and $40 \mu \mathrm{M}$ of arsenate as described above. Three replicates were run for each concentration. At $18 \mathrm{~h}$ post exposure, all the remaining cells in flasks were finally collected by centrifugation and freeze dried in a Freeze Dryer (Labconco Corporation, USA). Freeze-dried cells were extracted with $5 \mathrm{ml}$ of $1 \%$ nitric acid in a microwave-accelerated reaction system according to Zhu et al. (2008). The temperature was gently raised, first to $55^{\circ} \mathrm{C}$ and then to $75^{\circ} \mathrm{C}$, with holding times of $10 \mathrm{~min}$. Finally, the digest was heated at $95^{\circ} \mathrm{C}$ for 30 min before cooling. The extract solutions were centrifuged and passed through nylon filters with a pore size of $0.45 \mu \mathrm{m}$. Filtrates were kept on ice and in the dark, and analyzed within a few hours after extraction. 
For arsenic speciation analysis of the culture medium, the microwave digestion step is not necessary. In brief, $1 \mathrm{ml}$ of the culture medium was centrifuged at $10,000 \times g, 4{ }^{\circ} \mathrm{C}$ for $5 \mathrm{~min}$. Then the supernatants were passed through nylon filters with a pore size of $0.45 \mu \mathrm{m}$, and kept on ice and in the dark for further processing.

Arsenic speciation was measured by a high-performance liquid chromatography-inductively coupled plasma-mass spectrometry (HPLC-ICP-MS) (7500cx Agilent Technologies, USA). Chromatographic columns consisted of a Hamilton precolumn $(25 \mathrm{~mm} \times 2.3 \mathrm{~mm})$ and a Hamilton PRP-X100 $10 \mu \mathrm{m}$ anion-exchange column $(250 \mathrm{~mm} \times 4.1 \mathrm{~mm})$. The mobile phase consisted of $6.67 \mathrm{mM}$ ammonium nitrate $\left(\mathrm{NH}_{4} \mathrm{NO}_{3}\right)$, adjusted to $\mathrm{pH} 6.2$ using ammonia. Arsenic species in the samples were identified by comparing their retention times with those of the standards, including arsenite [As (III)], arsenate [As (V)], monomethylarsonic acid (MMA), and dimethylarsinic acid (DMA), and quantified by external calibration curves with peak areas.

\section{Extraction of proteome for 2D gel electrophoresis}

Proteomes were extracted following the protocol described by Huang et al. (2010). T. pyriformis cells $(3 \mathrm{ml})$ in late exponential growth phase were pelleted by centrifugation $\left(10,000 \times g, 4^{\circ} \mathrm{C}, 5 \mathrm{~min}\right)$, rinsed three times with washing buffer and stored at $-80^{\circ} \mathrm{C}$ until further processing. For protein extraction, frozen cells were thawed on ice and resuspended with $0.3 \mathrm{ml}$ of extraction buffer. During extraction, samples were ice-incubated and vortexed for 15 s every $5 \mathrm{~min}$. Cellular debris was removed by centrifugation $(10,000 \times g$, $\left.4{ }^{\circ} \mathrm{C}, 5 \mathrm{~min}\right)$. Protein concentrations were assayed using the Quick Start Bradford Protein Assay Kit 1 (Bio-Rad) following the manufacturer's instructions.

For two-dimensional polyacrylamide gel electrophoresis (2D-PAGE), the first dimension separation of proteins was performed with $18 \mathrm{~cm}$ IPG strips ( $\mathrm{pH} \mathrm{4-7} \mathrm{and} \mathrm{pH}$ 7-10) in an IPGphore system (GE Healthcare). 2D-PAGE was conducted using $150 \mu \mathrm{g}$ of total protein, with three replicates in each treatment. The isoelectric focusing program was in accordance with Huang et al. (2010). After the first dimension, the IPG strips were treated with Equilibration buffer I and Equilibration buffer II (Bio-Rad) for $15 \mathrm{~min}$ each.

The second dimension of 2D-PAGE was performed using $12.5 \%$ SDS-polyacrylamide gels in the Protean II XL (BioRad) system at $100 \mathrm{~V}$ for $30 \mathrm{~min}$, and then at $200 \mathrm{~V}$ for $5-6 \mathrm{~h}$. Proteins in gels were visualized by post-electrophoretic staining with SYPRO Ruby and scanned using the Gene Genius Bio Imaging System (Syngene). Images were analyzed and quantitatively compared using ImageMaster 2D Platinum 5.0 software. Differentially expressed proteins showing a greater than or equal to 1.5 fold changes were marked in the gels.

\section{Protein identification by mass spectrometry}

Differentially expressed protein spots were manually excised from gels using Pasteur pipettes and digested as described by Shevchenko et al. (1996). Tryptic peptides were analyzed by matrix-assisted laser desorption/ionization timeof-flight mass spectrometry (MALDI TOF MS) and MS/MS. Data from MALDI TOF MS/MS were analyzed using the search software MASCOT (Matrix Science). A protein score of higher than 83 and at least 3 matched peptides per protein were set as the threshold for positive identification.

\section{Results}

\section{Toxic effects of arsenate to T. pyriformis}

Under six different treatments with increasing arsenate concentrations ranging from 0 to $200 \mu \mathrm{M}$, arsenate began to inhibit the growth of $T$. pyriformis within a few hours, and the growth rate was reduced significantly with increasing arsenate concentrations (Fig. 1).

Based on the growth curves of T. pyriformis under arsenate exposure, the 18-h $\mathrm{EC}_{50}$ arsenate concentration, causing a $50 \%$ decrease in growth rate of $T$. pyriformis, was calculated to be ca. $40 \mu \mathrm{M}$. To understand whether arsenate could cause any other characteristic alterations, the cell mobility and morphology of $T$. pyriformis were investigated under a treatment with $40 \mu \mathrm{M}$ arsenate. The results showed that, in the first $9 \mathrm{~h}$ of arsenate exposure, no significant changes were observed, when compared to the control. At the late exponential growth phase, however, the toxic effects began to appear, reflected by a much lower swimming velocity of $T$. pyriformis in the medium. About $18 \mathrm{~h}$ of exposure, significant morphological changes were found in most of the treated cells. The cell body became a little shorter and stouter. Meanwhile, the cell surface of arsenate-treated T. pyriformis became riddled with a number of depressions ranging in diameter from 0.3 to $0.5 \mu \mathrm{m}$ (Fig. 2). In contrast, when T. pyriformis cells were investigated in $30 \mu \mathrm{M}$ of arsenate, no significant growth inhibition was found.

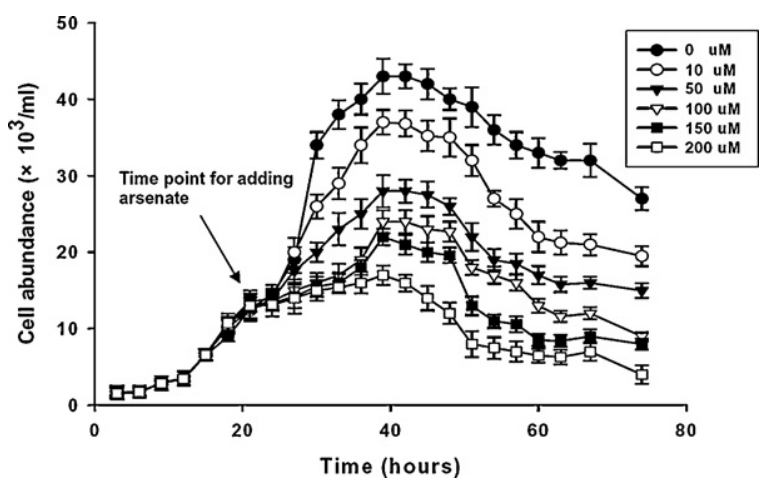

Fig. 1. Growth curves of T. pyriformis exposed to different concentrations of arsenate. Data are mean \pm SE, $n=3$. 

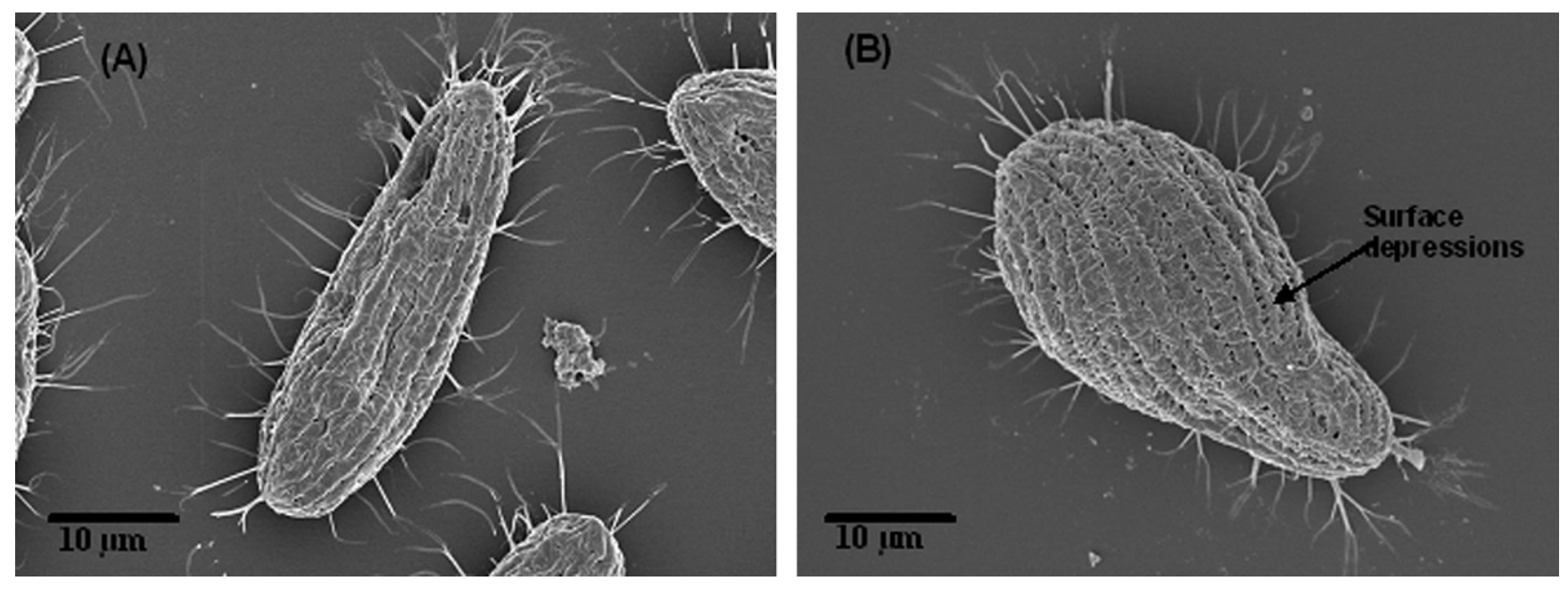

Fig. 2. Scanning electron microscopic photographs of $T$. pyriformis at stationary growth phase under treatment with (A) 0 and (B) $40 \mu \mathrm{M}$ of arsenate. The holes formed at the surface of arsenate-treated cells are marked with the arrow.

\section{Arsenic speciation in T. pyriformis and the medium}

Arsenic speciation analysis showed that most intracellular As (V) of T. pyriformis was transformed to As (III), and the methylated derivates of MMA (V) and DMA (V) (Fig. 3). The transformation rate reached as high as $94 \%$ and $98 \%$ in the cells under treatments with 0.67 and $40 \mu \mathrm{M}$ of As (V), respectively. Among them, the most abundant species were DMA (V) and MMA (V) (Fig. 3).

Meanwhile, we found that both As (III) and DMA (V) in T. pyriformis could be rapidly and continuously excreted from the cell, resulting in an increasing accumulation of As (III) and DMA (V) and a decrease of As (V) in the medium. Whereas, very little MMA (V) was detected in the medium (Fig. 4).

\section{Protein expression changes of $T$. pyriformis under arsenate exposure}

Fig. 5 shows the representative $\mathrm{pH} 4-7$ and 7-10 2Dgel maps for normal control (Fig. 5A, C) and treated cells with $30 \mu \mathrm{M}$ arsenate for $18 \mathrm{~h}$ (Fig. 5B, D). The protein pattern varies among the representative 2D-gel maps. Arsenate affected the expression of 59 protein spots with more than 1.5 fold changes in intensity, and there were 26 and 33 proteins up-regulated and down-regulated in treated cells compared with controls, respectively (Fig. 5). MALDI-TOF MS/MS analyses of the 59 proteins yielded high scores for 30 proteins which are summarized in Table 1. According to the Clusters of Orthologous Groups of proteins (COGs) database of NCBI, the functions of 22 protein spots were successfully determined, while the other 8 spots were annotated as hypothetical proteins. Interestingly, several protein spots that were located at different positions in the 2D gels were identified as the same protein, such as spots 5 and 7 were both identified as the hypothetical protein XCV0130, both spots 11 and 27 were identified as the ATP synthase beta chain, and both spots 23 and 48 were identified as alpha-tubulin (Table 1). It suggests that some kind of posttranslational modifications may have occurred in these proteins (Zhang et al. 2009a,b).

\section{Discussion}

\section{Arsenate toxicity and resistance}

As reported previously, arsenic is toxic to biological organisms mainly by short-circuiting life's main energy-generation system, affecting respiration, and promoting the intracellular accumulation of reactive oxygen species (Jimi et al. 2004). In this study, the most easily recognized symptom of arsenate toxicity was the growth inhibition of T. pyriformis. Meanwhile, the lower swimming velocity and abnormal cell shape are also visible reflections of the arsenate cytotoxicity. However, no dead cells were found during the exponential growth phase of T. pyriformis under exposure with as high as $200 \mu \mathrm{M}$ of arsenate, suggesting a certain resistance of this organism.

In fact, T. pyriformis could grow reasonably well in a medium containing up to $30 \mu \mathrm{M}$ of arsenate, revealing this protozoan does have some capacity to mitigate against arsenic toxicity. This shows T. pyriformis can thrive in a moderately contaminated environment.

\section{Arsenate resistance via biomethylation and rapid exportation}

Our results revealed that $94-98 \%$ of the total arsenate in cells of T. pyriformis could be transformed to monomethylarsonic acid, dimethylarsinic acid and a small proportion of arsenite after $18 \mathrm{~h}$ of arsenate exposure. As is known to all, the toxicity of As (V) is much higher than DMA (V) and MMA 

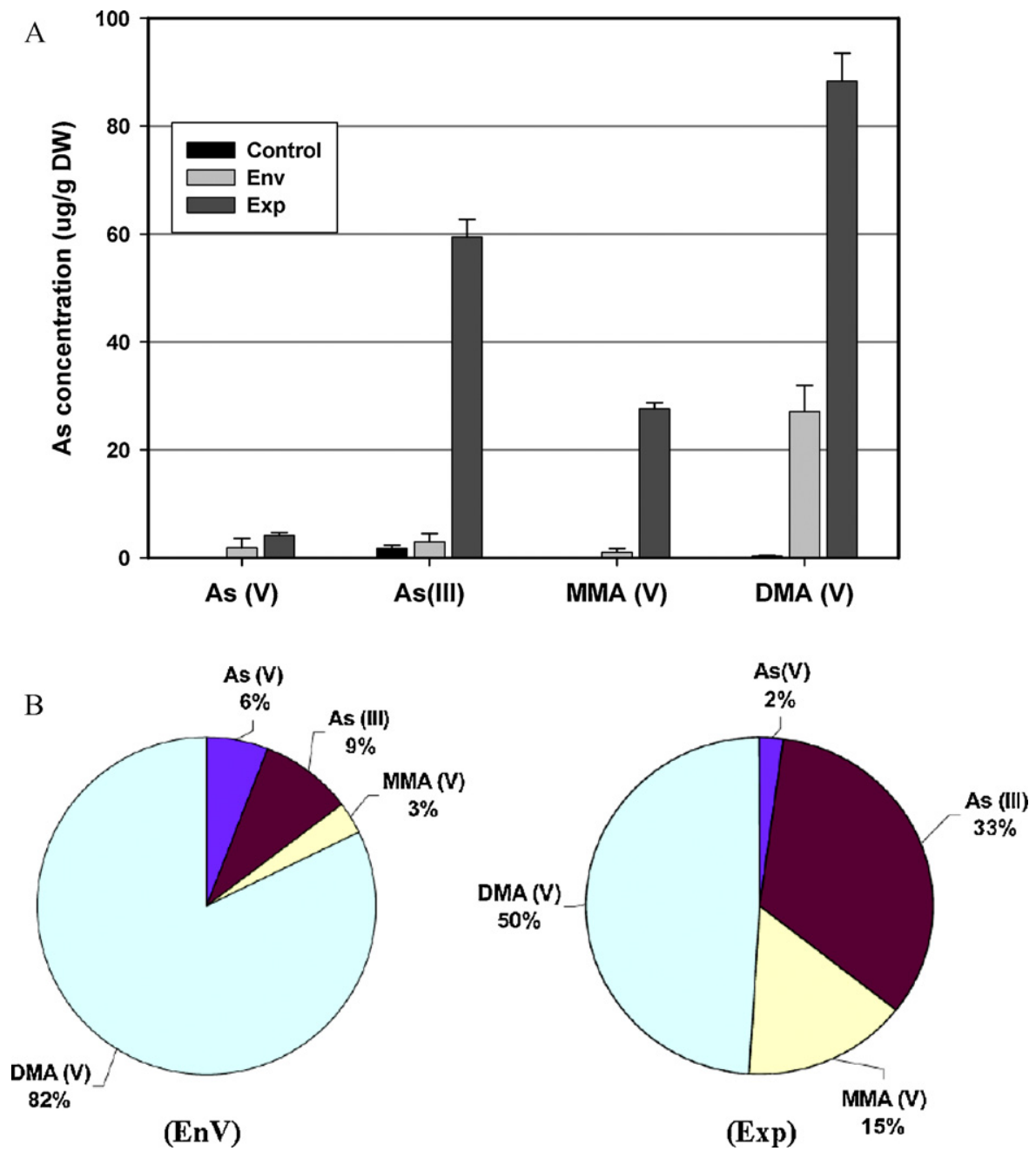

Fig. 3. Arsenic speciation analysis in the cells of T. pyriformis. (A) Concentrations of different arsenic species in T. pyriformis exposed to $0 \mu \mathrm{M}$ (Control), ca. $0.67 \mu \mathrm{M}(50 \mathrm{ppb})$ (Env) and $40 \mu \mathrm{M}$ (Exp) of arsenate for $18 \mathrm{~h}$. (B) Intracellular proportions of different arsenic species in T. pyriformis exposed to ca. $0.67 \mu \mathrm{M}$ (Env) and $40 \mu \mathrm{M}$ (Exp) of arsenate for $18 \mathrm{~h}$.

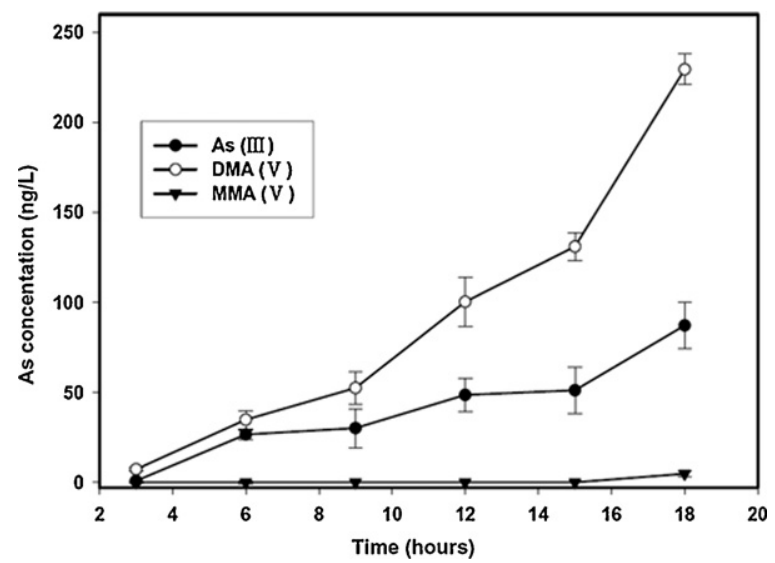

Fig. 4. Time course accumulation of As (III), MMA (V), and DMA (V) in the culture medium of $T$. pyriformis exposed to $40 \mu \mathrm{M}$ of arsenate. Data are mean $\pm \mathrm{SE}, n=3$.
(V). Thus, we consider that oxidation/reduction and methylation is likely one of the major detoxification pathways in T. pyriformis, a detoxification mechanism existing widely in many other microorganisms, such as bacteria, fungi, yeast, and algae, as well as some higher animals (Bhattacharjee and Rosen 2007; Tsai et al. 2009).

Arsenic methylation is a multi-step process that involves a reduction of As (V) to As (III) and a sequence of methylation and reoxidation to MMA (V) and DMA (V) (Mukhopadhyay et al. 2002; Tsai et al. 2009). In this study, it can be seen obviously that the proportion and concentration of As (III) within the cells exposed to $40 \mu \mathrm{M}$ arsenate was much higher than those treated with $0.67 \mu \mathrm{M}$ arsenate (Fig. 3). We suppose that the toxic effects of arsenate $(40 \mu \mathrm{M})$ to $T$. pyriformis was likely due to a saturation of the methylation processes, leading to the accumulation of As (III) and subsequent toxicity. Thus, our results indicate the growth of $T$. pyriformis was more directly associated with the activity of As (III) in the cell than the concentration of As (V) in the medium. 

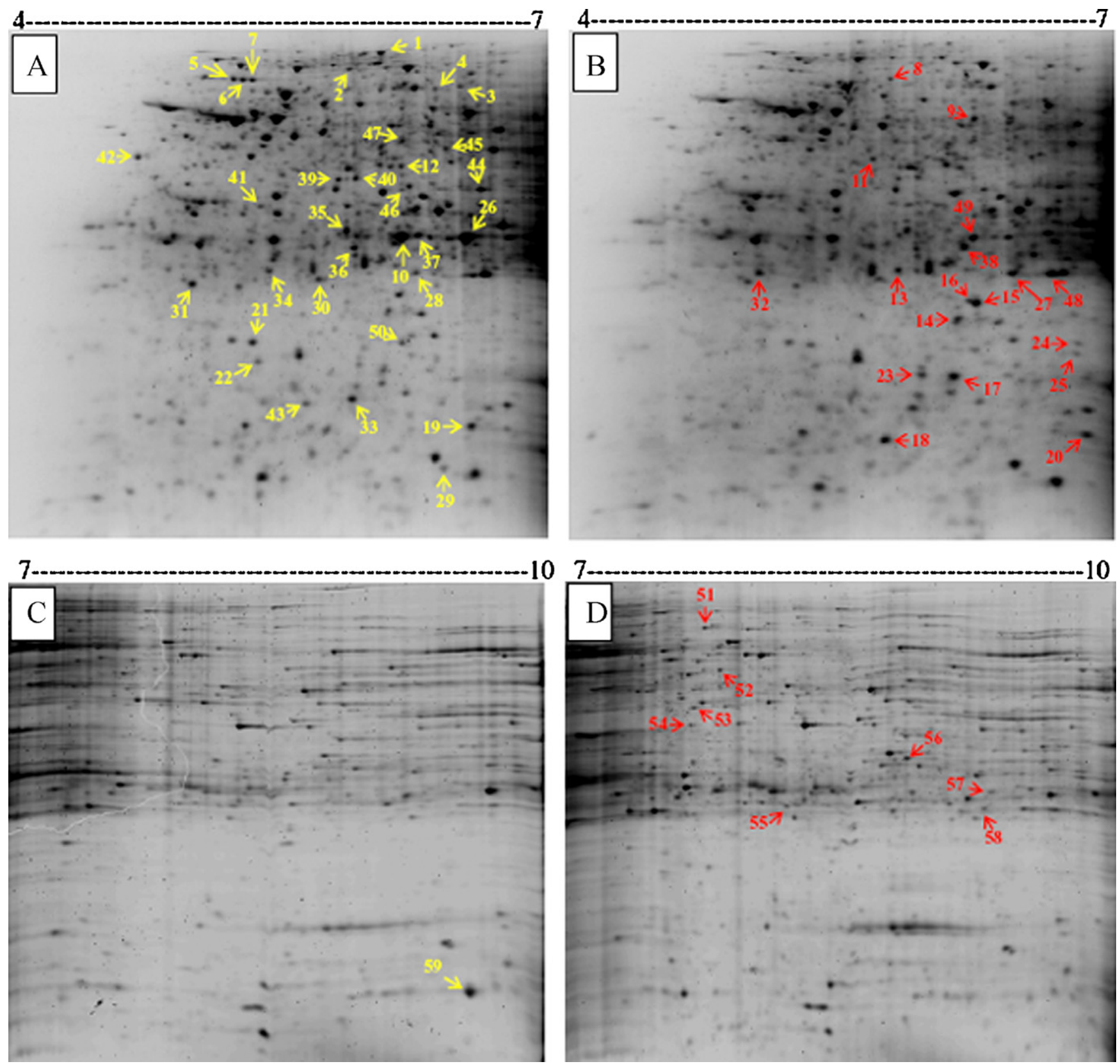

Fig. 5. 2D-gel maps showing protein expression changes in T. pyriformis cells upon arsenate induction. In electrophoresis, the proteins were first separated using the IPG strips with $\mathrm{pH}$ ranges of 4-7 and 7-10, separately. (A, C) The control cells; (B, D) cells treated with 30 $\mu \mathrm{M}$ arsenate for $18 \mathrm{~h}$. The red-marked spots were up-regulated ( $\geqq 1.5$ fold) and the yellow-marked spots were down-regulated ( $\geqq 1.5$ fold). (For interpretation of the references to color in this figure legend, the reader is referred to the web version of the article.)

To reduce the cytotoxicity of intracellular As (III), many organisms, from bacteria (e.g. Escherichia coli) to humans, have evolved efficient As (III) transport systems catalyzing its extrusion, such as the arsRBC system in bacteria (Bhattacharjee and Rosen 2007; Rosen and Liu 2009) and MRP (multidrug resistance-associated protein) in eukaryotes (e.g. fungi) (Bhattacharjee and Rosen 2007). In this study, we found that $T$. pyriformis could also rapidly and continuously excrete As (III) and DMA (V) into the medium. Whereas, very little MMA (V) was excreted (Fig. 4). These results are consistent with the findings of Yin et al. (2011). We suppose that as a transient intermediate, most MMA (V) was transformed to DMA (V) in cells before being excreted. Moreover, since the excreted As (III) can be further methylated to MMA (V) and DMA (V), we suppose that in a moderately contaminated water environment, where T. pyriformis thrives, large part of the As (V) may be finally replaced by DMA (V), thus significantly reducing the toxic risks of the contaminated environment.

Yin et al. (2011) reported that T. pyriformis has a strong ability to biovolatilize arsenic. Since the volatile arsenic compounds can be released from water, resulting in loss of 
Table 1. Summary of the differently expressed proteins identified using MALDI-TOF MS/MS.

\begin{tabular}{|c|c|c|c|c|c|}
\hline Spot ID & Protein name & NCBI accession no. & Pep. count & Protein score & $\begin{array}{l}\text { Expression } \\
\text { change }\end{array}$ \\
\hline 2 & Aspartyl-tRNA synthetase family protein & Gi/118383039 & 13 & 167 & $\downarrow$ \\
\hline 3 & Hypothetical protein sorbidraft_04g032010 & $\mathrm{Gi} / 242062940$ & 20 & 85 & $\downarrow$ \\
\hline 5 & Hypothetical protein XCV0130 & $\mathrm{Gi} / 78045686$ & 19 & 96 & $\downarrow$ \\
\hline 6 & Coiled-coil Y protein & $\mathrm{Gi} / 18519043$ & 25 & 97 & $\downarrow$ \\
\hline 7 & Hypothetical protein XCV0130 & $\mathrm{Gi} / 78045686$ & 18 & 89 & $\downarrow$ \\
\hline 9 & Ubiquitin-activating enzyme & $\mathrm{Gi} / 118351055$ & 3 & 285 & $\uparrow$ \\
\hline 11 & $\begin{array}{l}\text { ATP synthase beta chain, mitochondrial } \\
\text { precursor, putative }\end{array}$ & Gi/146185860 & 17 & 776 & $\uparrow$ \\
\hline 13 & Hypothetical protein D2045.5 & $\mathrm{Gi} / 17552818$ & 18 & 85 & $\uparrow$ \\
\hline 14 & Two-component sensor histidine kinase & Gi/85717408 & 21 & 89 & $\uparrow$ \\
\hline 15 & Glutathione peroxidase family protein & $\mathrm{Gi} / 118362818$ & 3 & 99 & $\uparrow$ \\
\hline 16 & Hypothetical protein TTHERM_00283850 & Gi/146172036 & 3 & 130 & $\uparrow$ \\
\hline 17 & Phenylacrylic acid decarboxylase & $\mathrm{Gi} / 254822334$ & 4 & 91 & $\uparrow$ \\
\hline 22 & $\begin{array}{l}2 \mathrm{Fe}-2 \mathrm{~S} \text { iron-sulfur cluster binding domain } \\
\text { containing protein }\end{array}$ & Gi/118353159 & 4 & 152 & $\downarrow$ \\
\hline 23 & Alpha-tubulin & Gi/22037135 & 10 & 460 & $\uparrow$ \\
\hline 27 & $\begin{array}{l}\text { ATP synthase beta chain, mitochondrial } \\
\text { precursor, putative }\end{array}$ & Gi/146185860 & 11 & 149 & $\uparrow$ \\
\hline 34 & Deoxyribonuclease I & $\mathrm{Gi} / 21903354$ & 5 & 160 & $\downarrow$ \\
\hline 38 & Nesprin-1, putative & $\mathrm{Gi} / 242014262$ & 77 & 97 & $\uparrow$ \\
\hline 39 & Peptidase M16 inactive domain containing protein & $\mathrm{Gi} / 229594165$ & 8 & 250 & $\downarrow$ \\
\hline 40 & Nuance & Gi/17016967 & 63 & 87 & $\downarrow$ \\
\hline 43 & Hypothetical protein TTHERM_00641250 & $\mathrm{Gi} / 118364240$ & 7 & 255 & $\downarrow$ \\
\hline 44 & $\begin{array}{l}\text { Oxidoreductase, zinc-binding dehydrogenase } \\
\text { family protein }\end{array}$ & Gi/118377036 & 8 & 115 & $\downarrow$ \\
\hline 46 & $\begin{array}{l}\text { Coproporphyrinogen III oxidase, aerobic family } \\
\text { protein }\end{array}$ & $\mathrm{Gi} / 118399273$ & 8 & 125 & $\downarrow$ \\
\hline 48 & Alpha-tubulin & $\mathrm{Gi} / 238617653$ & 7 & 236 & $\uparrow$ \\
\hline 49 & Hypothetical protein LC705_00884 & $\mathrm{Gi} / 258539075$ & 35 & 100 & $\uparrow$ \\
\hline 51 & aldehyde dehydrogenase (NAD) family protein & $\mathrm{Gi} / 118398425$ & 10 & 358 & $\uparrow$ \\
\hline 52 & Citrate synthase & Gi/156723169 & 18 & 341 & $\uparrow$ \\
\hline 53 & Enolase family protein & $\mathrm{Gi} / 118362946$ & 3 & 152 & $\uparrow$ \\
\hline 55 & $\begin{array}{l}\text { Thioredoxin-dependent peroxide reductase } \\
\text { mitochondrial precursor }\end{array}$ & Gi/118359822 & 3 & 162 & $\uparrow$ \\
\hline 56 & Heat shock protein 70 (HSP70) & $\mathrm{Gi} / 66356390$ & 10 & 237 & $\uparrow$ \\
\hline 58 & Hypothetical protein TTHERM_01227760 & $\mathrm{Gi} / 229596058$ & 3 & 120 & $\uparrow$ \\
\hline
\end{tabular}

arsenic from both the medium and the cells, biovolatilization was considered another important and effective detoxification pathway for T. pyriformis.

As protozoa are abundant and widespread in global aquatic ecosystems, if the strong ability of arsenic biomethylation and biovolatilization of $T$. pyriformis is not just a special case, but commonly exists among other ciliate or protozoa groups, the protozoa-mediated transformation of arsenic is proposed to have an important impact on the global arsenic cycles.

\section{Proteomic responses to arsenate exposure}

Recently, 2D-PAGE was proven to be an effective method for investing the proteome of Tetrahymena cells (Xanthopoulou et al. 2010). At the global protein level, comparative proteomics was employed to investigate the stress responses of $T$. pyriformis to arsenate exposure. Our results revealed that the expression of 59 protein spots changed significantly with more than 1.5 fold in intensity under arsenate exposure. Among them, 30 proteins were successfully identified using MALDI-TOF MS/MS (Table 1). According to the functional categories, these changed proteins are functionally classified into the following six groups.

(1) Structural proteins. Exposure to arsenate induced a significant change in the expression of three structural proteins, i.e., the up-regulated alpha-tubulin and nesprin1 and one down-regulated protein, nuance (also called nesprin-2 giant). Tubulin can serve as a high-affinity binding site for As (III) and involve in the biological action of As (III) (Jayanarayan and Dey 2002). Nesprin-1 and nuance are members of the nesprins protein family. They help position intracellular organelles by tethering them with the outer nuclear membrane and the 
actin cytoskeleton, and have an important role in forming and maintaining nuclear structures (Kandert et al. 2007; Mellad et al. 2011). Under arsenate exposure, the expression changes of alpha-tubulin, nesprin-1, and nuance could be indicative of a structural reorganization, resulting in the significant morphological changes observed (Fig. 2) and lower swimming velocity of T. pyriformis.

(2) Oxidoreductase proteins. As reported previously, generating reactive oxygen species (ROS) and free radicals like hydrogen peroxide $\left(\mathrm{H}_{2} \mathrm{O}_{2}\right)$, hydroxyl radical species $(\mathrm{HO})^{\bullet}$ and superoxide anion $\left(\mathrm{O}_{2}{ }^{\bullet-}\right)$, is one of the major pathways of arsenic cytotoxicity (Del Razo et al. 2001). These reactive intermediates can induce apoptosis by impairing DNA or reacting with cellular constituents such as thiols and lipids (Del Razo et al. 2001). Under arsenate stress, two antioxidant enzymes [i.e., thioredoxin-dependent peroxide reductase (spot 55) and glutathione peroxidase family protein (spot 15)] were over-expressed in T. pyriformis. Both are enzymes of the peroxidase family proteins that can reduce $\mathrm{H}_{2} \mathrm{O}_{2}$ and lipid hydroperoxides (Chae et al. 1994). Here, the upregulation of these two enzymes is likely involved in arsenate resistance by protecting the cells from oxidative damage.

Moreover, the down-regulation of two other oxidoreductase proteins was also found in the treated cells. They are the coproporphyrinogen III oxidase (spot 46) and zinc-binding dehydrogenase family protein (spot 44). Since coproporphyrinogen oxidase is the sixth enzymatic step in the heme biosynthetic pathway (Zagorec and Labbe-Bois 1986), the down-regulation of coproporphyrinogen III oxidase may indicate a repression of the synthesis of heme under arsenate stress.

(3) Chaperone and proteolysis related proteins. Exposure to arsenic either in vitro or in vivo in a variety of model systems could cause the induction of a number of heat shock proteins (Hsp) (Del Razo et al. 2001). Hsp can act as "chaperone" to maintain the homeostasis of the cell by facilitating the folding, assembly, and distribution of newly synthesized proteins. Meanwhile, they are involved directly in the protection and repair of vulnerable protein targets and DNA repair (Del Razo et al. 2001). As a member of the Hsp protein family, the Hsp 70 (spot 56) was found to be up-regulated in the arsenate treated cells. We suppose that its elevated expression is involved in the defense against arsenate-induced oxidative damage, by preventing protein denaturation and misfolding, and DNA damage.

However, it is possible that some misfolded or damaged polypeptides would remain to be repaired within cells. To maintain the normal cell physiology, it is important to clear the non-functional and potentially toxic proteins by selective protein destruction or degradation mechanisms. Among them, the ubiquitin-dependent proteolysis is a major pathway with particular importance for protecting cells against harsh conditions (Goldberg
2003). In this study, the up-regulation of ubiquitinactivating enzymes (spot 9) in the treated cells may indicate a promotion of ubiquitin-dependent proteolysis, i.e. defending against the arsenate toxicity by preventing the accumulation of toxic proteins.

(4) Enzymes of energy metabolism. The expression of several enzymes involved in energy metabolism was significantly enhanced in the arsenate treated cells, including aldehyde dehydrogenase (NAD) family protein (spot 51), ATP synthase beta chain (spots 11 and 27), citrate synthase (spot 52), enolase family protein (spot 53), and phenylacrylic acid decarboxylase (spot 17).

Since arsenic can interfere with the electron transport chain and influence ATP production (Bona et al. 2010), the increased expression of these enzymes might protect cells against arsenate toxicity by increasing the energy production in T. pyriformis.

(5) Two-component signal transduction protein. Twocomponent signaling systems are the principal means for coordinating responses to environmental changes in prokaryotes as well as some plants, fungi and protozoa (Stock et al. 2000). Previous studies have revealed that the two-component signal transduction system could regulate arsenite oxidation in bacteria (Kashyap et al. 2006). Here under arsenate stress, the two-component sensor histidine kinase (spot 14) was also over-expressed in T. pyriformis. We suppose that the two-component signaling systems were likely involved in the biological activities of arsenate.

(6) Hypothetical proteins and proteins of unknown function. Among the listed proteins in Table 1, there are eight proteins with significant expression changes being identified as hypothetical proteins, such as the spots 3, 5, $7,13,16,43,49$ and 58. In addition, although another five down-regulated proteins (spots 2, 6, 22, 34 and 39) were identified successfully, their detailed functions in the stress responses to arsenate are still unclear so far, and remain an open question.

In conclusion, from the proteomic results, we consider that the resistance to arsenate toxicity in $T$. pyriformis was through the following pathways: (1) enhancing the scavenging activity of free radicals to prevent oxidative damages; (2) employing the ubiquitin-dependent proteolysis to avoid accumulation of misfolded or damaged polypeptides that are toxic to cells; (3) raising the sugar metabolic efficiency to supply more energy for arsenic extrusion. However, it is worth noting that although arsenic speciation analysis revealed that arsenate reduction, the subsequent biomethylation and biovolatilization, and efficient arsenic extrusion are the major pathways for arsenate detoxification, homologs of the several remarkable enzymes dominating these processes were not detected in this study, such as the arsenate reductases for As (III) production, arsenite methylases for the generation of MMA (V), DMA (V) and other volatile derivates, and the arsABC in prokaryotes or MRP in eukaryotes for As (III) 
efflux (Bhattacharjee and Rosen 2007). This is likely because the intracellular contents of these typical enzymes are too low to be detected by the current 2D-PAGE technique, or some unknown enzymatic systems which are not homologous to the above described remarkable enzymes might be employed by T. pyriformis for arsenate detoxification. Although the As (III) efflux mechanisms have been extensively studied in various organisms (Oremland and Stolz 2003), little is known about the mechanisms of DMA (V) efflux. We believe that $T$. pyriformis would be a good candidate organism for studying the mechanism of DMA (V) efflux. Sequencing of the whole genome of T. pyriformis is presently underway in our laboratory; we believe that in the near future the available genome sequence will provide a most powerful background to reveal the complex metabolic activities of arsenic in T. pyriformis.

\section{Acknowledgements}

This study was supported by the China International Science and Technology Cooperation Program (No. 2009DFB90120), the Knowledge Innovation Program of the Chinese Academy of Sciences (No. KZCX2-YW-QN401), the National Natural Science Foundation of China (No. 41006087), and the Key Science and Technology Project of Fujian Province, China (No. 2009Y0044 and 2010J05089). Xiaojing Zhu, Bin Xu and Guoxin Sun are thanked for their technical help with SEM and HPLC-ICP-MS. Paul Williams is thanked for his help with the English.

\section{References}

Alvarado, S., Guédez, M., Lué-Merú, M.P., Nelson, G., Alvaro, A., Jesús, A.C., Gyula, Z., 2008. Arsenic removal from waters by bioremediation with the aquatic plants Water Hyacinth (Eichhornia crassipes) and Lesser Duckweed (Lemna minor). Biores. Technol. 99, 8436-8440.

Amaral, M.D., Galego, L., Rodrigues-Pousada, C., 1988. Stress response of Tetrahymena pyriformis to arsenite and heat shock: differences and similarities. Eur. J. Biochem. 171, 463-470.

Bhattacharjee, H., Rosen, B., 2007. Arsenic metabolism in prokaryotic and eukaryotic microbes. In: Nies, D.H., Silver, S. (Eds.), Molecular Microbiology of Heavy Metals. Springer-Verlag, Berlin, Germany, pp. 371-406.

Bona, E., Cattaneo, C., Cesaro, P., Marsano, F., Lingua, G., Cavaletto, M., Berta, G., 2010. Proteomic analysis of Pteris vittata fronds: two arbuscular mycorrhizal fungi differentially modulate protein expression under arsenic contamination. Proteomics 10, 3811-3834.

Čerňanský, S., Urík, M., Ševc, J., Khun, M., 2007. Biosorption and biovolatilization of arsenic by heat-resistant fungi. Environ. Sci. Pollut. Res. 14, 31-35.

Chae, H.Z., Chung, S.J., Rhee, S.G., 1994. Thioredoxindependent peroxide reductase from yeast. J. Biol. Chem. 269, 27670-27678.
Corliss, J.O., 2002. Biodiversity and biocomplexity of the protists and an overview of their significant roles in maintenance of our biosphere. Acta Protozool. 41, 199-220.

Del Razo, L.M., Quintanilla-Vega, B., Brambila-Colombres, E., Calderón-Aranda, E.S., Manno, M., Albores, A., 2001. Stress proteins induced by arsenic. Toxicol. Appl. Pharm. 177, 132-148.

Finlay, B.J., Esteban, G.F., 1998. Freshwater protozoa: biodiversity and ecological function. Biodivers. Conserv. 7, 1163-1186.

Goldberg, A.L., 2003. Protein degradation and protection against misfolded or damaged proteins. Nature 426, 895-899.

Hahn, M.W., Höfle, M.G., 2001. Grazing of protozoa and its effect on populations of aquatic bacteria. FEMS Microbiol. Ecol. 35, $113-121$.

Huang, C.X., Zhang, Y.Y., Jiao, N.Z., 2010. Phage resistance of a marine bacterium, Roseobacter denitrificans OCh114, as revealed by comparative proteomics. Curr. Microbiol. 61, 141-147.

Jayanarayan, K., Dey, C., 2002. Resistance to arsenite modulates expression of $\beta$ - and $\gamma$-tubulin and sensitivity to paclitaxel during differentiation of Leishmania donovani. Parasitol. Res. 88, 754-759.

Jimi, S., Uchiyama, M., Takaki, A.Y.A., Suzumiya, J., Hara, S., 2004. Mechanisms of cell death induced by cadmium and arsenic. Ann. N. Y. Acad. Sci. 1011, 325-331.

Kandert, S., Lüke, Y., Kleinhenz, T., Neumann, S., Lu, W., Jaeger, V.M., Munck, M., Wehnert, M., Müller, C.R., Zhou, Z., 2007. Nesprin-2 giant safeguards nuclear envelope architecture in LMNA S143F progeria cells. Hum. Mol. Genet. 16, 2944-2959.

Kapaj, S., Peterson, H., Liber, K., Bhattacharya, P., 2006. Human health effects from chronic arsenic poisoning - a review. J. Environ. Sci., Health Part A 41, 2399-2428.

Kashyap, D.R., Botero, L.M., Franck, W.L., Hassett, D.J., McDermott, T.R., 2006. Complex regulation of arsenite oxidation in Agrobacterium tumefaciens. J. Bacteriol. 188, 1081-1088.

Liao, C.M., Jau, S.F., Chen, W.Y., Lin, C.M., Jou, L.J., Liu, C.W., Liao, V.H.C., Chang, F.J., 2008. Acute toxicity and bioaccumulation of arsenic in freshwater clam Corbicula fluminea. Environ. Toxicol. 23, 702-711.

Matschullat, J., 2000. Arsenic in the geosphere - a review. Sci. Total Environ. 249, 297-312.

Mellad, J.A., Warren, D.T., Shanahan, C.M., 2011. Nesprins LINC the nucleus and cytoskeleton. Curr. Opin. Cell Biol. 23, 47-54.

Mukhopadhyay, R., Rosen, B.P., Phung, L.T., Silver, S., 2002. Microbial arsenic: from geocycles to genes and enzymes. FEMS Microbiol. Rev. 26, 311-325.

Oremland, R.S., Stolz, J.F., 2003. The ecology of arsenic. Science 300, 939-944.

Qin, J., Rosen, B.P., Zhang, Y., Wang, G., Franke, S., Rensing, C., 2006. Arsenic detoxification and evolution of trimethylarsine gas by a microbial arsenite S-adenosylmethionine methyltransferase. Proc. Natl. Acad. Sci. U.S.A. 103, 2075-2080.

Rosen, B.P., Liu, Z., 2009. Transport pathways for arsenic and selenium: a minireview. Environ. Int. 35, 512-515.

Sauvant, N.P., Pepin, D., Piccinni, E., 1999. Tetrahymena pyriformis: a tool for toxicological studies. Chemosphere 38, 1631-1669.

Shevchenko, A., Wilm, M., Vorm, O., Mann, M., 1996. Mass spectrometric sequencing of proteins from silver-stained polyacrylamide gels. Anal. Chem. 68, 850-858. 
Stock, A.M., Robinson, V.L., Goudreau, P.N., 2000. Twocomponent signal transduction. Annu. Rev. Biochem. 69, 183-215.

Tchounwou, P.B., Centeno, J.A., Patlolla, A.K., 2004. Arsenic toxicity, mutagenesis, and carcinogenesis - a health risk assessment and management approach. Mol. Cell. Biochem. 255, $47-55$.

Tsai, S.L., Singh, S., Chen, W., 2009. Arsenic metabolism by microbes in nature and the impact on arsenic remediation. Curr. Opin. Biotechnol. 20, 659-667.

Tseng, C.H., Tseng, C.P., Chiou, H.Y., Hsueh, Y.M., Chong, C.K., Chen, C.J., 2002. Epidemiologic evidence of diabetogenic effect of arsenic. Toxicol. Lett. 133, 69-76.

Xanthopoulou, A.G., Anagnostopoulos, D., Vougas, K., Anagnostopoulos, A.K., Alexandridou, A., Spyrou, G., Siafaka-Kapadai, A., Tsangaris, G.T., 2010. A two-dimensional proteomic profile of Tetrahymena thermophila whole cell lysate. In Vivo 24, 443-456.
Yin, X.X., Zhang, Y.Y., Yang, J., Zhu, Y.G., 2011. Rapid biotransformation of arsenic by a model protozoan Tetrahymena pyriformis. Environ. Pollut. 159, 837-840.

Zagorec, M., Labbe-Bois, R., 1986. Negative control of yeast coproporphyrinogen oxidase synthesis by heme and oxygen. J. Biol. Chem. 261, 2506-2509.

Zhang, X., Zhao, F.J., Huang, Q., Williams, P.N., Sun, G.X., Zhu, Y.G., 2009a. Arsenic uptake and speciation in the rootless duckweed Wolffia globosa. New Phytol. 182, 421-428.

Zhang, Y.Y., Jiao, N.Z., Colquhoun, R.D., Halden, U.R., Chen, F., 2009b. Protein modifications related to phage resistance in a marine roseobacter. Aquat. Microb. Ecol. 55, 203-207.

Zhu, Y.G., Sun, G.X., Lei, M., Teng, M., Liu, Y.X., Chen, N.C., Wang, L.H., Carey, A.M., Deacon, C., Raab, A., Meharg, A.A., Williams, P.N., 2008. High percentage inorganic arsenic content of mining impacted and nonimpacted Chinese rice. Environ. Sci. Technol. 42, 5008-5013. 